\title{
Zapotrzebowanie środowiska szkolnego w zakresie edukacji ekonomicznej a oferta edukacyjna Portalu Edukacji Ekonomicznej Narodowego Banku Polskiego - NBPortal.pl
}

Wprowadzenie w ostatnich latach do programu nauczania w szkołach ponadgimnazjalnych przedmiotu podstawy przedsiębiorczości zwiększyło ilość organizowanych w Polsce inicjatyw sprzyjających rozwojowi edukacji ekonomicznej. Inicjatorami tych działań są organizacje pozarządowe, media oraz organy administracyjne.

Narodowy Bank Polski w 2003 r. rozpoczął prowadzenie Portalu Edukacji Ekonomicznej - NBPortal.pl, którego jednym z celów jest pogłębianie wiedzy ekonomicznej.

\section{Praktyka realizowania przedmiotu podstawy przedsiębiorczości w szkołach}

Na zlecenie Narodowego Banku Polskiego Centralny Ośrodek Doskonalenia Nauczycieli przeprowadził badania, które dostarczają informacji na temat praktyki realizowania podstaw przedsiębiorczości w wybranych szkołach. Badaniom poddano nauczycieli, doradców metodycznych, dyrektorów szkół oraz uczniów. Trwały one od marca do kwietnia 2005 r. Podstawowym ich celem było określenie rodzaju i poziomu wykształcenia nauczycieli uczących podstaw przedsiębiorczości, sposobów realizacji w szkołach tego przedmiotu oraz poznanie potrzeb edukacyjnych nauczycieli, opinii nauczycieli o treściach zawartych w podstawie programowej i opinii uczniów na temat przedmiotu podstawy przedsiębiorczości.

Uzyskano odpowiedzi 1029 nauczycieli, 10 doradców metodycznych, 414 dyrektorów szkół, 1081 uczniów z całego kraju. Oprócz tego w 21 szkołach przeanalizowano dokumentację nauczania podstaw przedsiębiorczości jako studium przypadku.

Z pytań dotyczących sylwetki nauczycieli podstaw przedsiębiorczości wynika, że w 94\% mają oni wyższe wykształcenie. Studia na kierunkach ekonomicznych ukończyło 51\% ankietowanych nauczycieli. Są oni doświadczeni zawodowo, staż pracy 59\% z nich to więcej niż 9 lat. Ich doświadczenie potwierdzają również stopnie awansu zawodowego - 73\% nauczycieli podstaw przedsiębiorczości ma stopień nauczyciela mianowanego lub dyplomowanego.

Większość nauczycieli ma kwalifikacje formalne do nauczania podstaw przedsiębiorczości (86\%). Zdaniem dyrektorów szkół do nauczania tego przedmiotu niezbędne są predyspozycje osobowościowe: przedsiębiorczość, zaradność, dynamizm, a także odpowiednie umiejętności i postawy: skuteczność, efektywność, dobra organizacja.

Prawie połowa nauczycieli uczy głównie podstaw przedsiębiorczości (49\%), dla 24\% głównym przedmiotem nauczania są podstawy ekonomii.

Niewystarczające przygotowanie merytoryczne do prowadzenia przedmiotu podstawy przedsiębiorczości dyrektorzy szkół oraz sami nauczyciele stwierdzają w obszarach: etyka w biznesie, rola banków w gospodarce, integracja Polski z Unią Europejską oraz planowanie i podejmowanie działalności gospodarczej. 
Ryc. 1. Potrzeby szkoleniowe z zakresu przedsiębiorczości w opinii dyrektorów szkół i nauczycieli według obszarów tematycznych

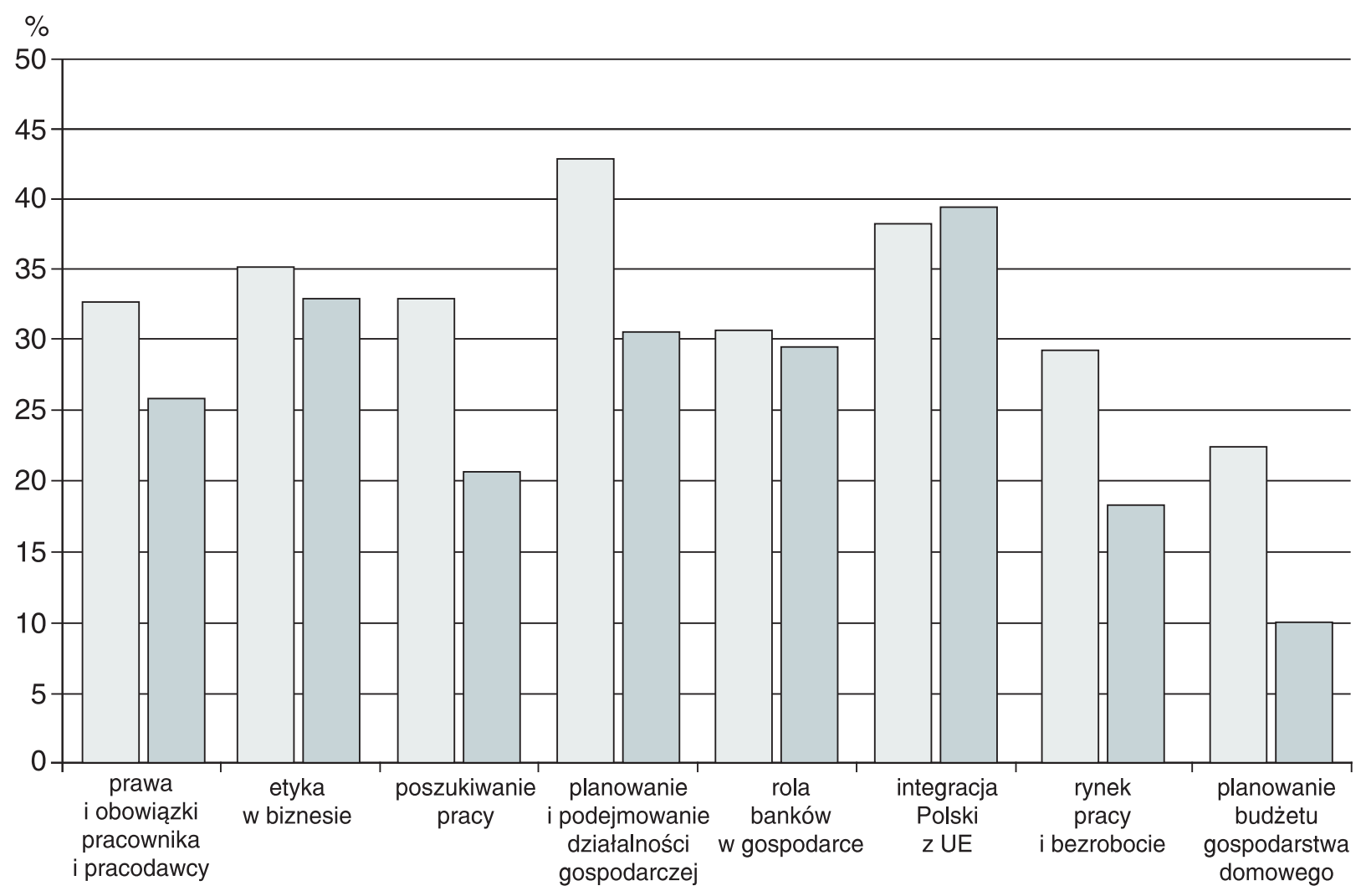

dyrektorzy $\square$ nauczyciele

Źródło: Raport zbiorczy z badań środowisk szkolnych w zakresie realizacji edukacji ekonomicznej w polskich szkołach ponadgimnazjalnych, praca zbiorowa, CODN 2005, materiał powielony.

Nauczyciele oczekują przede wszystkim szkoleń kształtujących umiejętności. Tymczasem dyrektorzy szkół uważają, że nauczycielom podstaw przedsiębiorczości umiejętności są potrzebne tylko przy realizacji tematów praktycznych, a tematy wymagające wiedzy wymagają od nich uczestnictwa w szkoleniach teoretycznych.

W opinii badanych nauczycieli, dyrektorów szkół oraz doradców metodycznych ranga przedmiotu podstawy przedsiębiorczości jest średnia i raczej niska. Respondenci rozumieją znaczenie przedmiotu, ale większą wagę przypisują przedmiotom maturalnym i na nich koncentrują wysiłki. Niska ranga przedmiotu związana jest z tym, że zdaniem badanych zabiera on czas, który mógłby zostać przeznaczony na realizację przedmiotów maturalnych.

Jednym z zasadniczych celów projektu badawczego było ustalenie opinii uczniów na temat przedmiotu podstawy przedsiębiorczości. Analizie poddano ogólną akceptację przedmiotu, ocenę praktycznej przydatności przedmiotu i ocenę poziomu trudności przekazywanych treści. Z badań wynika, że uczniowie są bardziej zainteresowani przedmiotem podstawy przedsiębiorczości niż ogólnie problematyką ekonomiczną. Najbardziej interesują ich tematy związane z poszukiwaniem pracy. Za ciekawe uznali tematy związane z rynkiem pracy, bezrobociem, planowaniem i podejmowaniem działalności gospodarczej oraz prawami i obowiązkami pracownika i pracodawcy. Mniej interesujące dla większości z nich są: planowanie budżetu gospodarstwa domowego oraz ekonomiczne konsekwencje integracji Polski z UE. Zagadnienia dotyczące roli banków w gospodarce i etyki w biznesie postrzegane są jako szczególnie mało interesujące. 
Ryc. 2. Ranga przedmiotu podstawy przedsiębiorczości w szkole w opinii dyrektorów i nauczycieli

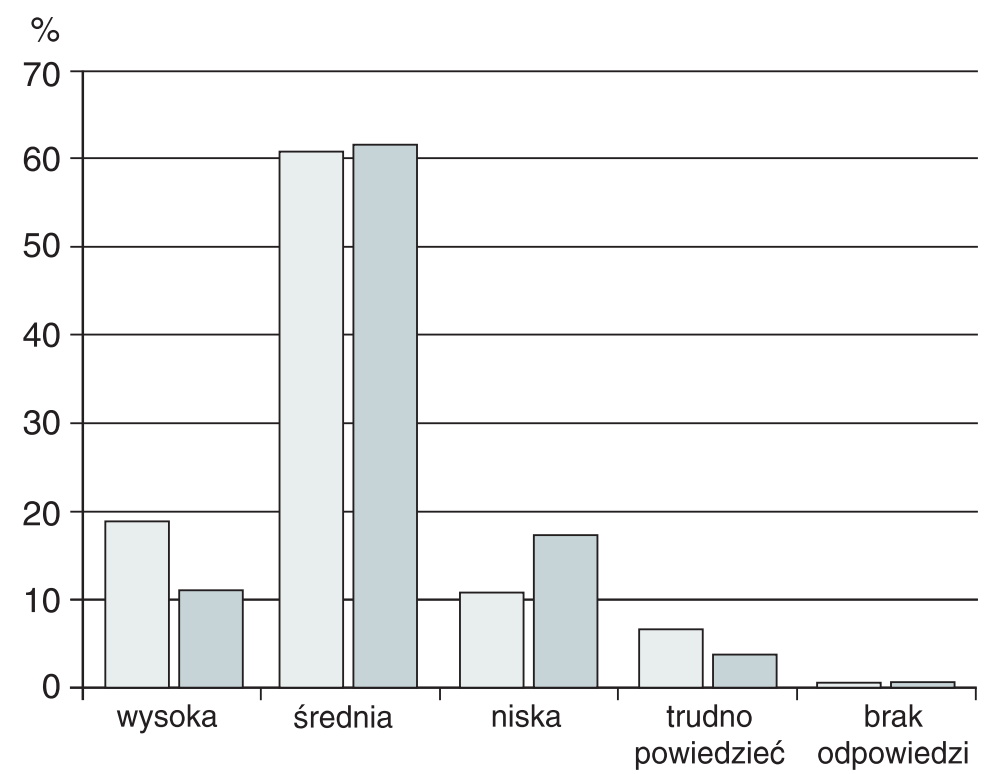

dyrektorzy $\square$ nauczyciele

Źródło: Raport zbiorczy z badań środowisk szkolnych w zakresie realizacji edukacji ekonomicznej w polskich szkołach ponadgimnazjalnych, praca zbiorowa, CODN 2005, materiał powielony.

Zdaniem badanych doradców metodycznych przedmiot jest lubiany i akceptowany tylko w tych szkołach, w których nauczyciele stosują nowoczesne (aktywizujące) metody nauczania i proponują uczniom zróżnicowane formy edukacji. Natomiast tam, gdzie nauczyciele stosują przede wszystkim metody podawcze, przedmiot postrzegany jest jak jeden z wielu innych i nie cieszy się sympatią, zwłaszcza że treści ekonomiczne nie należą do prostych, zatem prezentowanie ich w standardowy sposób (wykład) nie może wpływać pozytywnie na stosunek uczniów do przedmiotu.

Uczniowie ogólnie postrzegają przedmiot jako dość przydatny, ale nie są w pełni przekonani, że przygotowuje ich w dobrym stopniu do wejścia na rynek pracy. Stosunkowo najbardziej przekonani o użyteczności przedmiotu są uczniowie techników - więcej niż połowa z nich stwierdza, że podstawy przedsiębiorczości przygotowują ich do wejścia na rynek pracy. Najmniej zadowoleni z tej funkcji przedmiotu są uczniowie liceów ogólnokształcących (ponad 20\% odpowiada: ,nie przygotowuje”).

Pomimo przekonania o niskim poziomie trudności przedmiotu, sprawia on uczniom kłopoty. Wyniki testu wiedzy potwierdzają wysoki poziom trudności treści ekonomicznych w programie nauczania przedsiębiorczości. Średni wynik grupy nie sięgnął 8 punktów $(7,86)$ w 17 -punktowej skali, a wynikiem najczęstszym było 7 punktów. Duży kłopot sprawiły uczniom pytania związane z funkcjonowaniem banków oraz gospodarką pieniężną. Wykonalność poniżej 25\% uzyskano na pytania o obligacje, działalność banków, zawartość planu biznesowego; około $30 \%$ - na pytania o pojęcie trwałego wzrostu gospodarczego, umocnienie złotego wobec innych walut, Radę Polityki Pieniężnej, cele działalności NBP, aktualne ruchy cen w kraju; ponad $70 \%$ - na pytania o konkurencję w gospodarce rynkowej, procedury wymagane przy rozpoczynaniu działalności gospodarczej. 
Według uczniów, na lekcjach przedsiębiorczości ciagle przeważają wykłady i pogadanki $(70 \%)$ oraz dyskusje (67\%). Połowa uczniów wymienia także pracę w grupach (48\%). Praca z tekstem źródłowym, projekty edukacyjne oraz gry dydaktyczne są metodami stosowanymi przez nauczycieli raczej rzadko. Uczniowie chętnie widzieliby na lekcji częstsze wykorzystywanie internetu, prezentacji multimedialnych, programów komputerowych. Obecnie są to rzadko wykorzystywane źródła informacji, choć w komputery wyposażona jest niemal każda szkoła uczestnicząca w badaniu.

Młodzież ma niedosyt filmów dydaktycznych i gier; sporadyczne korzystanie z nowoczesnych źródeł informacji i pomocy dydaktycznych nauczyciele uzasadniają małą dostępnością pracowni komputerowych z internetem i rzutnikiem multimedialnym.

Zdaniem uczniów szersze wykorzystanie pomocy dydaktycznych, stosowanie różnych, atrakcyjnych, angażujących metod pracy, wzmocnienie praktycznego aspektu nauczania tego przedmiotu i wzmocnienie kontaktów z instytucjami i przedsiębiorstwami wpłynęłoby na zwiększenie ich zadowolenia z uczestnictwa w lekcjach podstaw przedsiębiorczości.

Na podstawy przedsiębiorczości przypadają dwie lekcje tygodniowo w całym cyklu kształcenia szkoły ponadgimnazjalnej. W większości szkoły decydują się na realizację jednej godziny przez dwa lata nauki. Ponad 80\% nauczycieli przedsiębiorczości stwierdziło, że nie ma wpływu na rozplanowanie godzin (tę decyzję podejmuje dyrekcja szkoły). Gdyby mieli wybór, zdecydowaliby się na dwie godziny łącznie przez jeden rok szkolny.

Nauczyciele rezygnują z aktywizujących metod w nauczaniu, gdyż są one czasochłonne, wymagają od nich zabiegów organizacyjnych (przejścia do pracowni komputerowej, wyjścia poza szkołę). Deklaruja, że najczęściej stosowane przez nich metody pracy to: burza mózgów, dyskusja, wykład, gry dydaktyczne i symulacja.

Badani uczniowie oceniają, że kolejność najczęściej stosowanych metod nauczania jest nieco inna niż deklarowana w badaniu przez nauczycieli: wykład 70\%, dyskusja $67 \%$, praca w grupach $48 \%$, praca z tekstem źródłowym $17 \%$, projekty edukacyjne $8 \%$, gry dydaktyczne $4 \%$.

Podstawowym środkiem dydaktycznym wskazywanym przez nauczycieli jest podręcznik. Ponad 80\% nauczycieli deklaruje również korzystanie z dodatkowych materiałów edukacyjnych: materiałów NBP, materiałów wydawnictw, organizacji pozarządowych, organizacji przedsiębiorców.

Uczniowie natomiast stwierdzili, że - oprócz podręczników - podstawowymi źródłami informacją są dla nich internet i telewizja.

Nauczyciele twierdzą, że najczęściej wykorzystywane w pracy z uczniami są środki dydaktyczne: foliogramy, literatura fachowa, internet, prasa fachowa. Jednocześnie stwierdzają potrzebę dostępu do: prezentacji multimedialnych, filmów dydaktycznych, programów komputerowych, gier dydaktycznych. Uczniowie także oczekują tych pomocy dydaktycznych.

Jednym z celów badania było ustalenie opinii nauczycieli, uczniów i doradców metodycznych o zawartości programowej przedmiotu podstawy przedsiębiorczości. Nauczyciele i doradcy informowali o przeładowaniu programu treściami edukacyjnymi. Podkreślali również wysoki poziom trudności materiału teoretycznego. Nauczycielom najwięcej trudności w przygotowaniu i przeprowadzeniu lekcji sprawiają teorie ekonomiczne.

Według zgodnej opinii uczniów, nauczycieli i doradców metodycznych wzmocnić należy następujące tematy: poszukiwanie pracy, planowanie i podejmowanie działalności gospodarczej, rynek pracy i bezrobocie. Treści zaś, które można zredukować, to etyka w biznesie. Nauczyciele twierdzą także, że mają one najsłabszą obudowę merytoryczną i materiałową. W opinii wszystkich grup respondentów można także ograniczyć zagadnienia: rola banków w gospodarce i planowanie budżetu gospodarstwa domowego. 
Ryc. 3. Deklarowane przez nauczycieli metody pracy stosowane na lekcjach przedsiębiorczości

$\%$
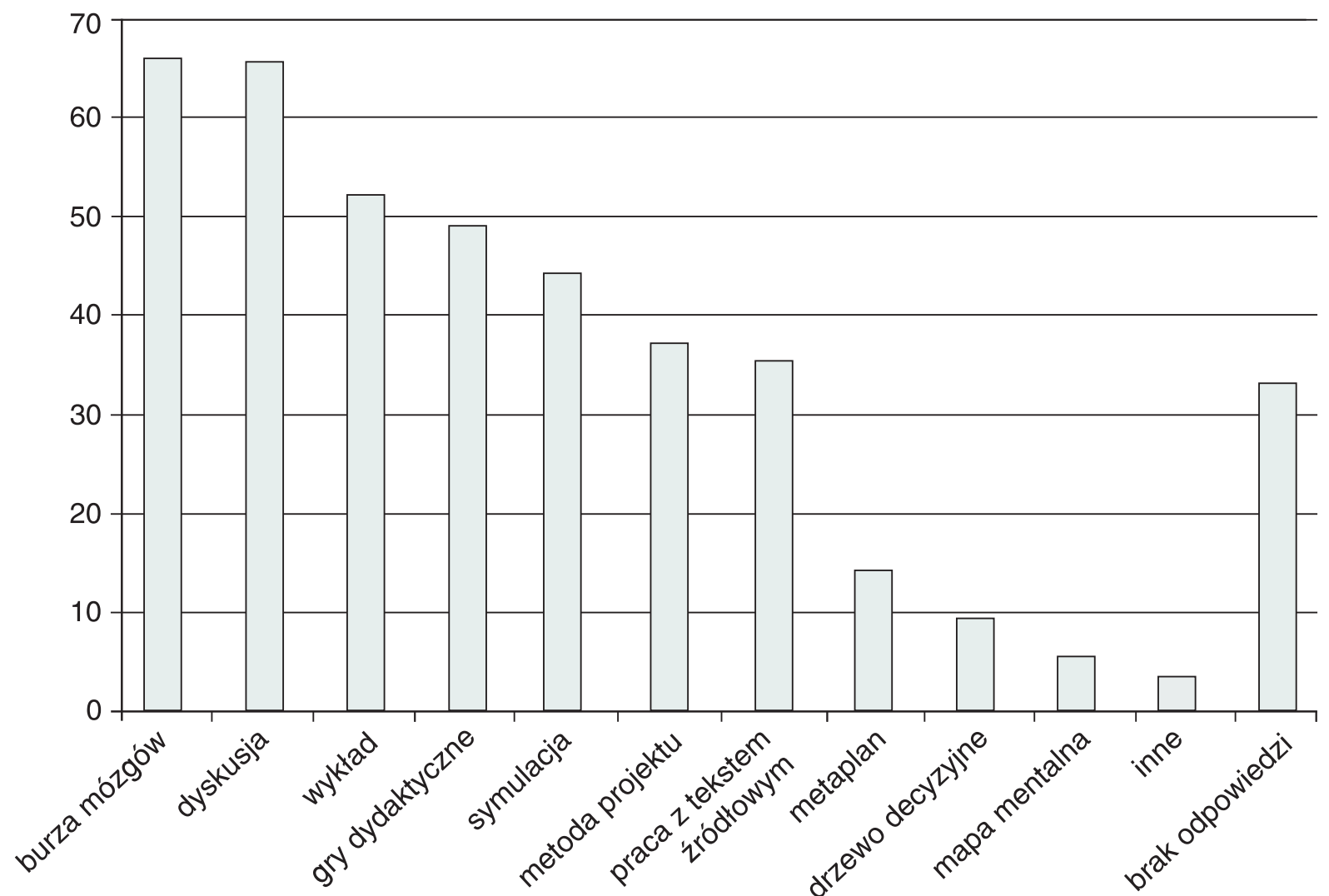

Źródło: Raport zbiorczy z badań środowisk szkolnych w zakresie realizacji edukacji ekonomicznej w polskich szkołach ponadgimnazjalnych, praca zbiorowa, CODN 2005, materiał powielony.

\section{NBPortal.pl - Portal Edukacji Ekonomicznej Narodowego Banku Polskiego}

Wyniki badań i opracowany na ich podstawie raport są ważną pomocą dla obecnych i przyszłych działań Portalu Edukacji Ekonomicznej Narodowego Banku Polskiego, który - wzorem innych banków centralnych - angażuje się w powszechną edukację ekonomiczną. Oferta edukacyjna NBPortal.pl wpisuje się w zapotrzebowanie edukacyjne uczniów, nauczycieli, dyrektorów szkół.

NBPortal.pl jest nowoczesną platformą edukacyjną, dostępną wszystkim użytkownikom internetu. Dostarcza wiedzy nie tylko uczniom, ale również nauczycielom.

NBPortal.pl oferuje ponad 200 godzin e-learningowych lekcji multimedialnych na temat Unii Europejskiej, euro, podstaw ekonomii, analizy finansowej firmy, pozyskiwania kapitału drogą kredytu bankowego, inwestowania oraz bankowości. Wymienione kursy zawierają te treści programu podstawy przedsiębiorczości (rola banków w gospodarce, integracja Polski z Unią Europejska, planowanie i podejmowanie działalności gospodarczej), które sprawiają szczególnie dużo trudności uczniom i tym nauczycielom, którzy nie mają wykształcenia ekonomicznego. Każdy kurs zamieszczony w NBPortal.pl składa się z kilkudziesięciu lekcji. Każda lekcja to kilkanaście minut multimedialnego wykładu z lektorem, animacje i krótkie filmy.

Kursy multimedialne dostosowują się do zaangażowania i możliwości czasowych użytkowników. Za sprawą specjalnego systemu zapamiętywane są fragmenty wiedzy już przyswojonej przez kursanta. Specjalny blok zatytułowany Twoje postępy, a także ćwiczenia i testy na bieżąco informują o postępach w nauce. Taka budowa kursu sprawia, że treść nauczania jest łatwiejsza do zapamiętania. 
Zdaniem uczniów na lekcjach przedsiębiorczości przeważają wykład i dyskusja, a chętniej widzieliby lekcje z wykorzystaniem internetu, prezentacji multimedialnych, programów komputerowych. Na stronach NBPortal.pl dostępnych jest kilkadziesiąt krótkich prezentacji oraz gier dydaktycznych dotyczących podstaw ekonomii. Prezentacje są doskonałym środkiem dydaktycznym, który można wykorzystać na 45-minutowej lekcji z uczniami. Pracę z prezentacją ułatwia przejrzysty układ ekranu, podział materiału na oddzielne rozdziały oraz możliwość samodzielnego ,przeskakiwania” materiału, w przód i w tył. Dzięki tym rozwiązaniom użytkownik prezentacji w wybranym przez siebie tempie może pogłębiać przekazywaną wiedzę.

Prezentacja pt. To nie Fenicjanie wymyśsili pieniądze

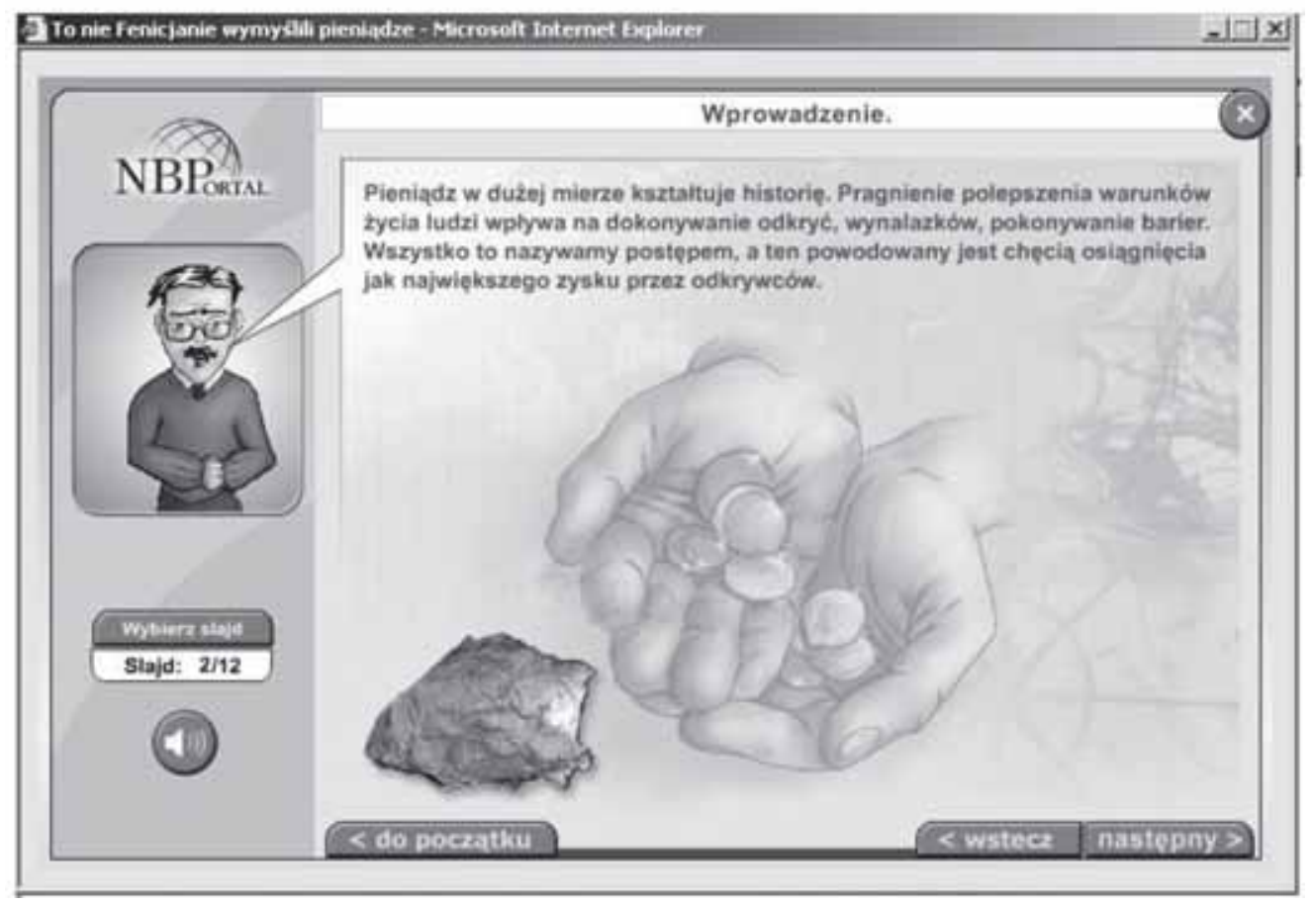

Opracowanie na podstawie http://www.nbportal.pl/pl/cw/prezentacje/prezentacje/to-nie-fenicjanie

Atrakcyjnym środkiem dydaktycznym, który można w prosty sposób wykorzystać, są multimedialne lekcje dla ucznia oraz dołączone do nich konspekty dla nauczycieli. Każda multimedialna lekcja dla ucznia to kilkanaście minut wykładu z lektorem, przeplatanego ćwiczeniami sprawdzającymi poziom zrozumienia treści.

Nauczyciele i dyrektorzy szkół doceniają rolę metod aktywizujących w pracy edukacyjnej, ale ich nie stosują. Uczniowie twierdzą, że najczęściej stosowane metody dydaktyczne to metody podawcze: wykład i dyskusja. Przedmiot jest lubiany przez uczniów w tych szkołach, w których nauczyciele stosują nowoczesne (aktywizujące) metody nauczania i proponują uczniom zróżnicowane formy edukacji.

NBPortal.pl proponuje naukę przedsiębiorczości przez zabawę, czyli gry strategiczne, quizy i krzyżówki.

Zabawy strategiczne i zręcznościowe nie tylko bawią, ale zmuszają do myślenia i zdobywania wiedzy ekonomicznej. Gry zostały oparte na modelach prawdziwych sytuacji ekonomicznych, dlatego wyzwania, przed jakimi zostaje postawiony internauta, są bardzo trudne. Uczeń może wziąć udział w symulacji zarządzania bankiem, w której wcieli się w rolę prezesa banku komercyjnego. Jego zadaniem będzie maksymalizowanie zysku banku, którym zarządza. Z kolei 
w grze „kasa nowa” zmierzy się z sytuacjami dnia codziennego - zarządzaniem budżetem domowym poprzez bilansowanie wydatków i przychodów. Gracz zadecyduje, czy zapłaci rachunek za telefon, pójdzie na studia podyplomowe, czy kupi samochód.

Multimedialna lekcja

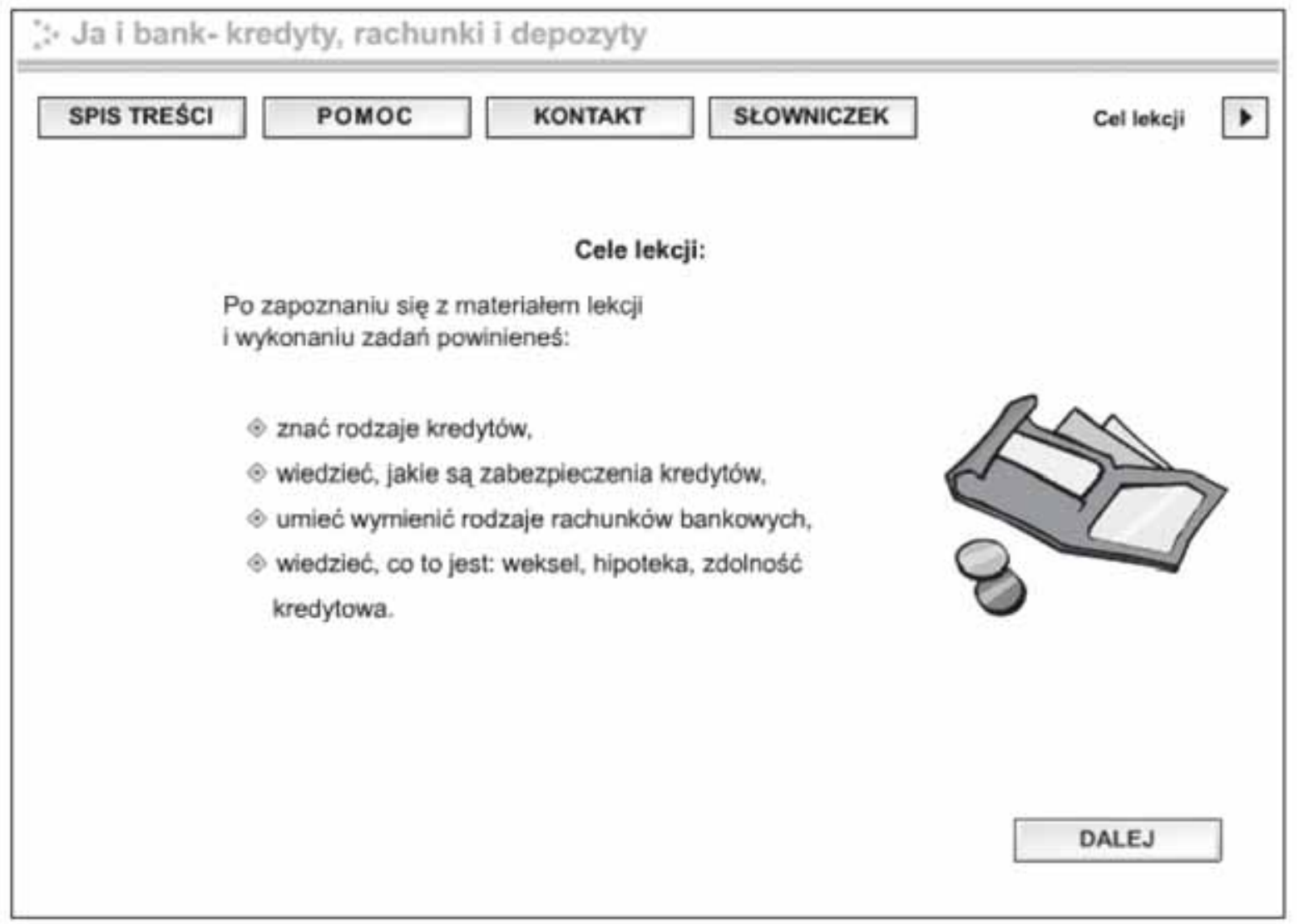

Opracowanie na podstawie http://www.nbportal.pl/pl/cn/dydaktyka/scenariusze/ja_i_bank

Zestaw kilkudziesięciu haseł zaczerpniętych z życia gospodarczego, politycznego i społecznego znajduje się krzyżówkach. Łączą one doskonałą rozrywkę z bardzo użyteczną wiedzą. Stanowią nieoceniony zbiór przydatnych terminów i pojęć, podanych w atrakcyjnej formie.

Nauczyciele najczęściej stwierdzają swoje niewystarczające przygotowanie merytoryczne w zakresie roli banków w gospodarce. Ponadto, jako trudne w realizacji ze względu na brak obudowy merytoryczno-dydaktycznej, wskazują zagadnienia dotyczące integracji Polski z UE oraz etyki w biznesie.

W NBPortal.pl znajdują się gotowe, szczegółowe konspekty lekcji, można je zatem bez kłopotu przygotować. Konspekty zaopatrzono w ćwiczenia dla uczniów, testy sprawdzające wiedzę, a także foliogramy.

W przygotowaniu zajęć z przedsiębiorczości mogą służyć pomocą materiały zawarte w wirtualnej bibliotece. Jest to wiarygodne źródło informacji, w którym znajdują się setki dostępnych w wersji elektronicznej publikacji: artykułów prasowych, książek, czasopism, raportów. Wszystkie materiały dostępne w bibliotece internauta można pobrać i zapisać w komputerze.

NBPortal.pl dostarcza narzędzi merytorycznych w postaci multimedialnych kursów e-learning, prezentacji, gier dydaktycznych, foliogramów oraz pomocy naukowych, jakimi są zbiory wirtualnej biblioteki, konspekty lekcji, wirtualny słownik ekonomiczny PWN. 
Portal Edukacji Ekonomicznej Narodowego Banku Polskiego - NBPortal.pl - we współpracy z instytucjami i organizacjami pozarządowymi uczestniczy w programach edukacyjnych mających na celu upowszechnianie wiedzy ekonomicznej, znajomości zasad funkcjonowania gospodarki rynkowej oraz promocji przedsiębiorczości.

Autor jest pracownikiem NBP. Artykuł wyraża jego osobiste poglądy.

\section{Literatura}

1. Raport z analizy 21 studiów przypadków $w$ szkołach ponadgimnazjalnych nt. środowiska szkolnego $w$ zakresie realizacji edukacji ekonomicznej, praca zbiorowa, CODN 2005, materiał powielony.

2. Raport z badania opinii doradców metodycznych i nauczycieli konsultantów, praca zbiorowa, CODN 2005, materiał powielony.

3. Raport z badania opinii dyrektorów szkót ponadgimnazjalnych $n t$. środowiska szkolnego $w$ zakresie realizacji edukacji ekonomicznej, praca zbiorowa, CODN 2005, materiał powielony.

4. Raport z badania opinii nauczycieli podstaw przedsiębiorczości nt. środowiska szkolnego w zakresie realizacji edukacji ekonomicznej $w$ polskich szkołach ponadgimnazjalnych, praca zbiorowa, CODN 2005, materiał powielony.

5. Raport zbiorczy z badań środowisk szkolnych $w$ zakresie realizacji edukacji ekonomicznej w polskich szkołach ponadgimnazjalnych, praca zbiorowa, CODN 2005, materiał powielony.

\section{Needs of the Economic Education vs. the Educational Offer of Polish National Bank's Portal of Economic Education (NBPortal.pl)}

In the last years the subject „bases for entrepreneurships” was included in the high school curriculum and it increased a number of initiatives propitious to the development of economic education. Non profit organizations, media and governmental agencies are promoters of these initiatives. The goal of this article is to present Polish National Bank's activities in subject matter, namely Portal of Economic Education - nbportal.pl - which sets itself the goal to improve economic education.

Furthermore author presents the effects of research ordered by the Polish National Bank in the Teachers' Development Center. They bring the information about practical aspects of the introduction of ,bases for entrepreneurships” in chosen Polish schools. The level and kind of education and methods of the implementation were the main goal of the research. Furthermore the research demonstrated the needs of the basis of entrepreneurship teachers, their opinions on the curriculum, and finally the students' opinion. 